\title{
Analyzing mechanical vibrations of an aircraft opposed piston engine
}

ARTICLE INFO

Received: 15 July 2021

Revised: 3 August 2021

Accepted: 11 August 2021

Available online: 23 August 2021
The paper presents the results of the bench tests to measure mechanical vibrations of a new aircraft opposed piston engine with reciprocating pistons. The PLZ-100 engine is a three-cylinder, six-piston, two-shaft drive unit with a two-stroke diesel cycle. This type of engine is dedicated for powering light aircraft, e.g. autogyros. The tests were carried out on a test bench at the Lublin University of Technology. The engine was loaded with constant torque, for several fixed values of rotational speed of a crankshaft. The angle of the start of diesel injection was changed for each of the rotational speeds. The mechanical vibrations that accompanied the operation of this drive unit were recorded with three measurement transducers and a National Instruments conditioning system. Each of the transducers was mounted on a different axis of the engine. The signals were analyzed from their diagrams with the DIAdem software. The results were the diagrams of effective speed and vibration acceleration to conduct a vibration-acoustic evaluation of the PLZ-100, detect and prevent various types of defects or failures.

Key words: DIAdem, mechanical vibrations, opposed pistons, PZL-100, vibroacoustics

This is an open access article under the CC BY license (http://creativecommons.org/licenses/BY/4.0/)

\section{Introduction}

Air transport is the transfer of people or goods by air. The main means of transport are aircraft in the categories of aeroplanes and helicopters. However, for individual transport, gyroplane are increasingly used $[4,5]$.

In contrast, internal combustion engines are commonly used to power aircraft, especially gyroplanes. The largest group includes piston aircraft engines. Compared to turbine engines, these engines are significantly cheaper and require less maintenance. Since their first use, aircraft engines have been continuously developed and modified. [3]. In addition, some manufacturers are attempting to use compression ignition engines or engines with reciprocating pistons to power aircraft $[7,8,15]$.

Two-stroke engines with opposed pistons have been known since 1890. They are used to drive road vehicles, marine vessels and even aircraft. [9, 15]. Engines of this type made a comeback after Achates Powers presented a three-cylinder engine with a capacity of $2.7 \mathrm{dm}^{3}$. Originally, the power unit was dedicated to drive vans. The engine was first unveiled at the 2015 international exhibition in Detroit. Series production, on the other hand, is expected to start as early as 2024 [1].

The opposed piston engine has a number of advantages and disadvantages in comparison with turbine engines. The advantages include, for example, the lack of a cylinder head - the combustion chamber is limited by two moving piston bottoms (with reciprocating motion). In addition, there is no need for a valve drive, which limits the loss of mechanical power.

The main disadvantage of the classical piston engine, as compared to turbine engines, is the mechanical vibrations generated due to the cyclic working process and the design of the piston-crank system. The engine with its heat generation process is a direct source of such oscillations. As well as a drop in the generated power, the vibrations may be transmitted to the structure of an aircraft or a vehicle, generating a high level of discomfort for the persons travelling in it $[6,9]$. Compression-ignition engines generate a high compression ratio, which translates into the generation of variable torque at the crankshaft. The high level of torsional vibration results in changes in torque transmitted not only to the drivetrain but also to the engine mounting. Therefore, opposed cylinder arrangements and a twostroke operating process are used to reduce mechanical vibrations [2]. Engines of this type have two opposing pistons always moving in the opposite direction (in one cylinder). These pistons are mechanically connected to their crankshafts, which are also mechanically connected. Therefore, relatively small loads are transferred to the engine block, which mitigates vibrations of the entire engine. Engines with reciprocating pistons are considered selfbalancing, without the need for additional mechanisms [10, $11,13]$.

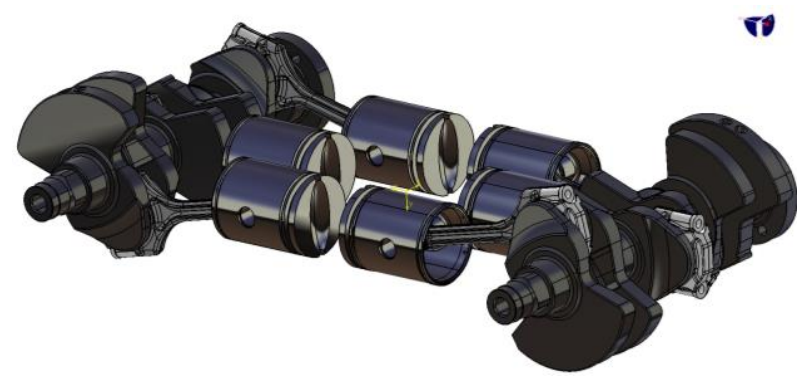

Fig. 1. Model of crank-piston system of PZL-100 engine in CAD environment

This paper presents the results of bench testing for measuring the mechanical vibrations of an engine with opposed pistons. This is a two-stroke, three-cylinder aircraft engine called PZL-100. The engine has two crankshafts and six pistons, which move against each other, but the rotation 
of the shafts is shifted in phase by 14 (Fig. 1). Understanding the level of vibration generated by the engine is essential for its correct installation and the selection of vibration isolators. Vibration analysis provides information about the technical condition of the engine during operation.

\section{Research object and test stand}

The object of the research was a prototype aircraft engine design with opposed pistons. The unit implements a two-stroke diesel cycle. The engine will be dedicated to propel gyroplanes. The PZL-100 engine has three cylinders and two opposed pistons in each of the cylinders. The engine generates $100 \mathrm{~kW}$ of mechanical power from a capacity of $1.5 \mathrm{dm}^{3}$. The propulsion unit was developed as part of the Diesel Engine for Aircraft Propulsion project carried out at the Lublin University of Technology.

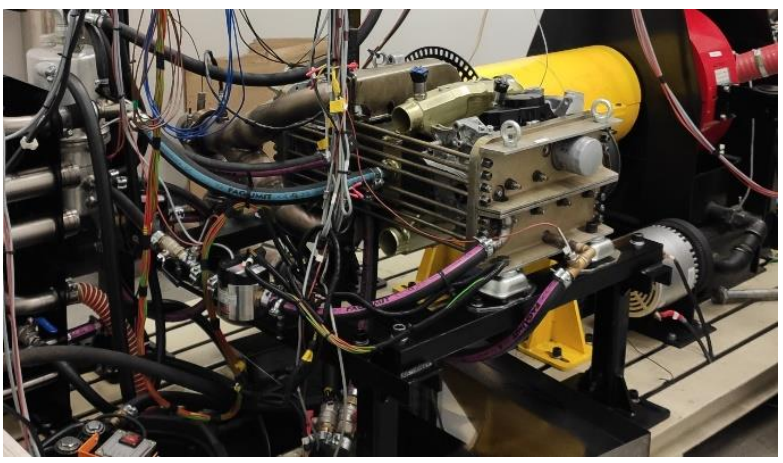

Fig. 2. PZL-100 engine on the test stand

A PZL 100 research engine installed on a brake stand in the Lublin University of Technology laboratory was tested within the scope of the research work (Fig. 2). This test stand was equipped with control and measurement systems allowing testing of the power unit under various operating conditions (load and crankshaft rotational speed). PCB sensors were used to record the vibration level - engine acceleration values (Table 1). Three sensors, for each engine axis, were installed on the engine block, as shown in Fig. 3.

Table 1. Features of the PCB352C03 sensor [14]

\begin{tabular}{|l|c|c|c|}
\hline Parameter & Unit & Value & \\
\hline Sensitivity & $\mathrm{mV} / \mathrm{g}$ & $10 \mathrm{mV} / \mathrm{g}$ \\
\hline $\begin{array}{l}\text { Measurement } \\
\text { range }\end{array}$ & $\mathrm{g} \mathrm{pk}$ & \pm 500 \\
\hline $\begin{array}{l}\text { Broadband } \\
\text { resolution }\end{array}$ & $\mathrm{g} \mathrm{rms}$ & 0.0005 \\
\hline $\begin{array}{l}\text { Frequency } \\
\text { range }\end{array}$ & $\mathrm{Hz}$ & $\begin{array}{l}0.5 \mathrm{to} \\
10000\end{array}$ \\
\hline $\begin{array}{l}\text { Sensing } \\
\text { element }\end{array}$ & - & Ceramic \\
\hline
\end{tabular}

The measurement signals were collected and conditioned using a module from National Instruments. It is a system control and real-time data archiving device for advanced applications. The platform used has a built-in network interface, which enables remote download of data recorded by the device.

The tests were carried out for a constant torque load of $25 \mathrm{Nm}$ on the drive unit. The engine drive shaft speed and injection start angle were changed during the tests. Figure 4 shows the location of all measurement points. In addition, for each accelerometer, individual signals for each of the three axes were recorded in real time.

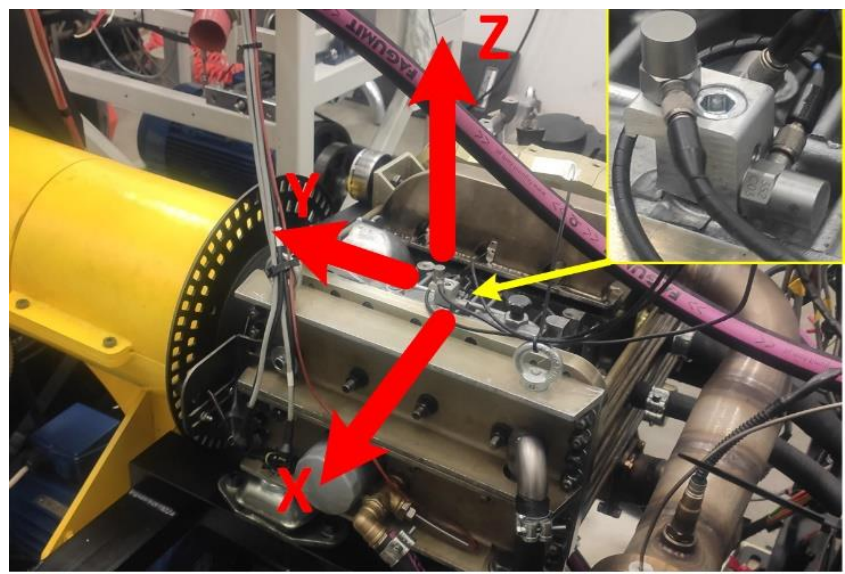

Fig. 3. Location of accelerometers on the test unit block (X-axis of cylinders, Y-axis of crankshaft, Y-vertical axis)

The conditioned signals were then archived and processed using DIAdem National Instrumensts software. In this software, the values of the signals from the vibration sensors were filtered, converted into units of velocity and acceleration, and the RMS values and RMS mean values were calculated. In addition, for a rotational speed of 3600 rpm, tests were carried out for torque values of: 50 and 75 $\mathrm{Nm}$. This speed is the cruising speed of the PZL 100 aircraft engine.

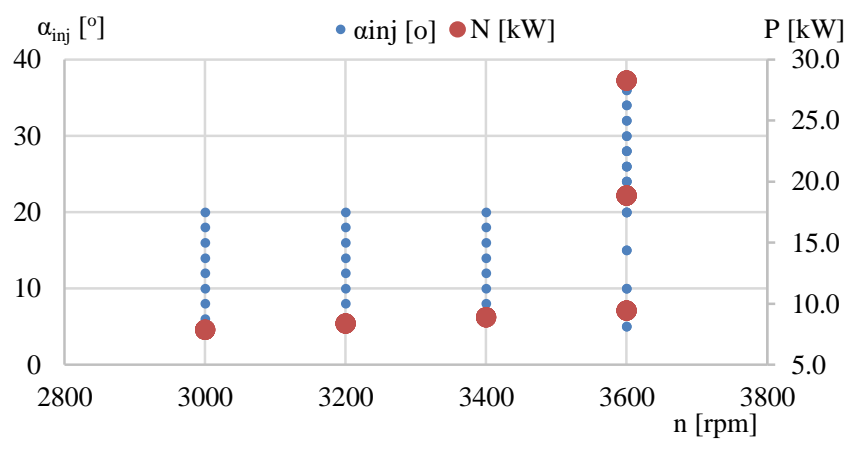

Fig. 4. Location of vibration test points on the PLZ-100 engine

\section{Results of bench tests}

For all measurement points during the vibration test of the PZL 100 engine, signals from accelerometers installed in three axes were recorded (Fig. 3):

- "X" - in the axis parallel to the axis of the cylinders (horizontal axis),

- "Y" - in the axis parallel to the crankshaft axis (horizontal axis, normal to the " $\mathrm{X}$ " axis),

- "Z" - in the vertical axis, normal to the "X" and "Y" axes".

Using DIAdem software from National Instruments, they were analysed. As a result of the analysis, the waveforms of the engine block vibration velocity, RMS velocity, acceleration and RMS acceleration were prepared. Example results were compiled for the engine crankshaft rotational speed corresponding to the cruising speed, $\mathrm{n}=3600 \mathrm{rpm}$, 
and the injection start angle $\alpha_{\text {inj }}=5^{\circ}(\operatorname{load} \mathrm{M}=75 \mathrm{Nm})-$ Figs 9-13.

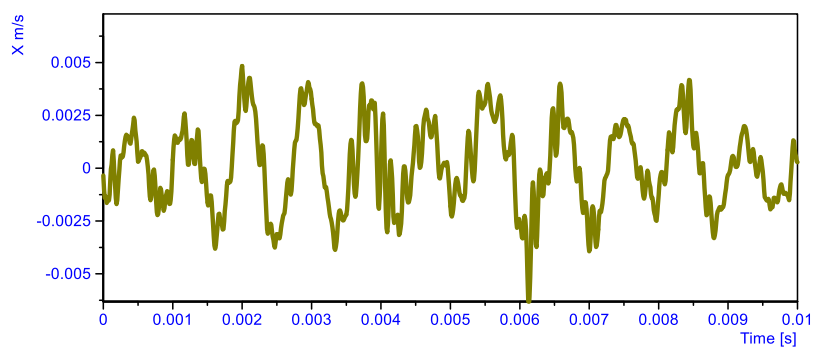

Fig. 5. The diagram of the vibration velocity in the $X$ axis; $n=3600 \mathrm{rpm}$, $\mathrm{M}=75 \mathrm{Nm}, \alpha_{\mathrm{wtr}}=5^{\circ}$

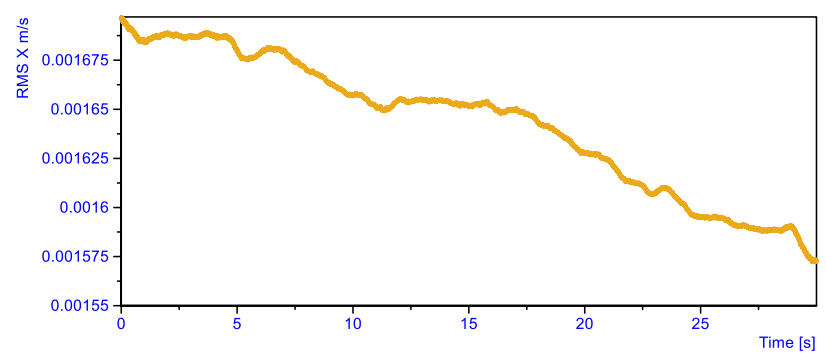

Fig. 6. The diagram of the effective RMS velocity of vibrations along the $\mathrm{X}$ axis; $\mathrm{n}=3600 \mathrm{rpm}, \mathrm{M}=75 \mathrm{Nm}, \alpha_{\mathrm{wtr}}=5^{\circ}$

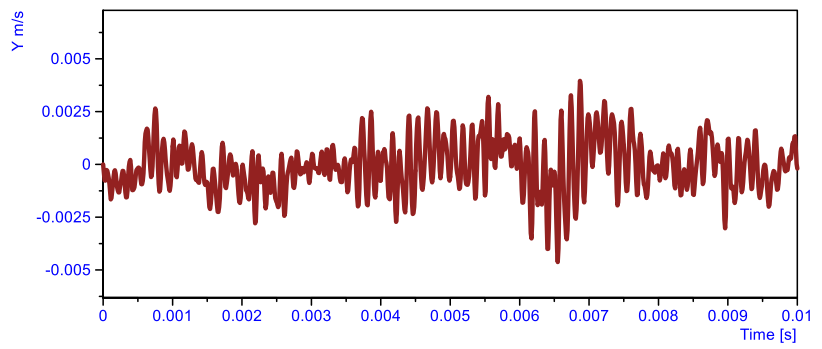

Fig. 7. The diagram of the vibration velocity in the $\mathrm{Y}$ axis; $\mathrm{n}=3600 \mathrm{rpm}$, $\mathrm{M}=75 \mathrm{Nm}, \alpha_{\mathrm{wtr}}=5^{\circ}$

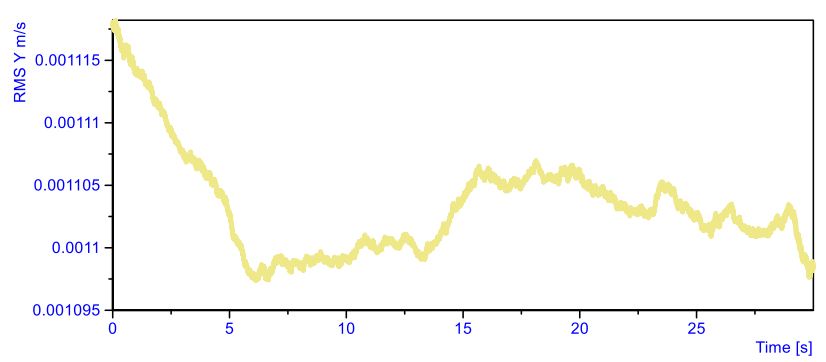

Fig. 8. The diagram of the effective RMS velocity of vibrations along the $\mathrm{Y}$ axis; $\mathrm{n}=3600 \mathrm{rpm}, \mathrm{M}=75 \mathrm{Nm}, \alpha_{\mathrm{wtr}}=5^{\circ}$

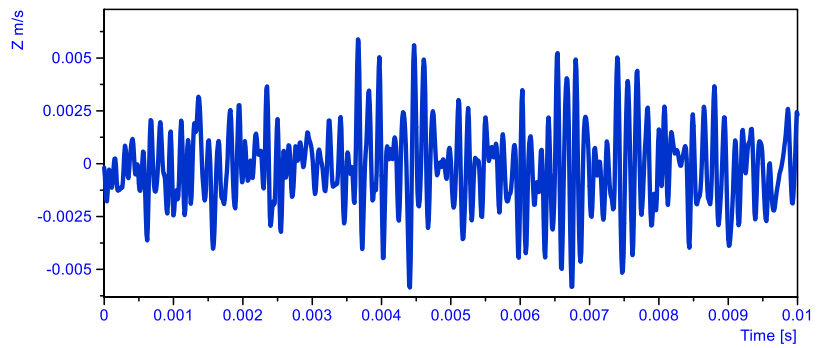

Fig. 9. The diagram of the vibration velocity in the $Z$ axis; $n=3600 \mathrm{rpm}$, $\mathrm{M}=75 \mathrm{Nm}, \alpha_{\mathrm{wtr}}=5^{\circ}$

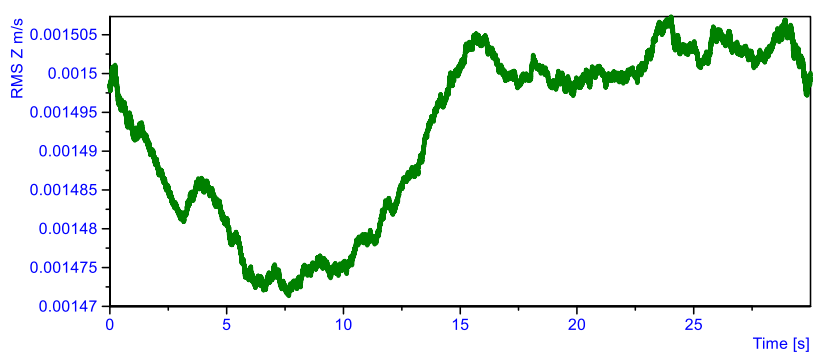

Fig. 10. The diagram of the effective RMS velocity of vibrations along the $\mathrm{Z}$ axis; $\mathrm{n}=3600 \mathrm{rpm}, \mathrm{M}=75 \mathrm{Nm}, \alpha_{\mathrm{wtr}}=5^{\circ}$

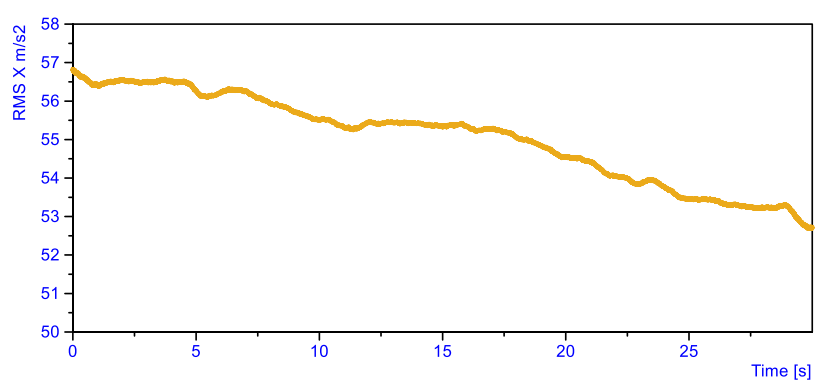

Fig. 11. The diagram of the effective RMS acceleration of vibrations along the $X$ axis; $n=3600 \mathrm{rpm}, M=75 \mathrm{Nm}, \alpha_{w t r}=5^{\circ}$

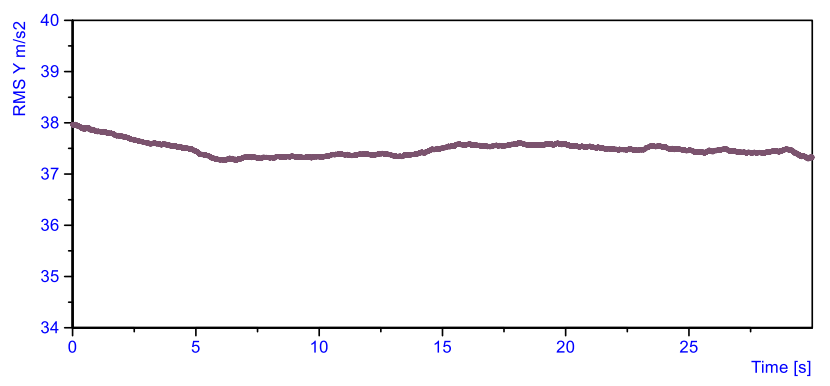

Fig. 12. The diagram of the effective RMS acceleration of vibrations along the $Y$ axis; $n=3600 \mathrm{rpm}, \mathrm{M}=75 \mathrm{Nm}, \alpha_{\mathrm{wtr}}=5^{\circ}$

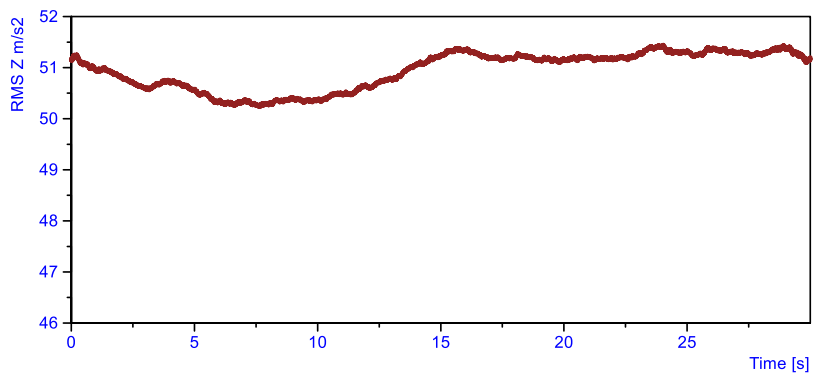

Fig. 13. The diagram of the effective RMS acceleration of vibrations along the $\mathrm{Z}$ axis; $\mathrm{n}=3600 \mathrm{rpm}, \mathrm{M}=75 \mathrm{Nm}, \alpha_{\mathrm{wtr}}=5^{\circ}$

\section{Summary}

As a result of the research work carried out and the analysis of their results, the diagrams of mechanical vibrations of the PLZ-100 engine were prepared. The engine was conditioned by bench tests for a constant load of the crankshafts with a torque of 25,50 and $75 \mathrm{Nm}$ (for power: 7.8 , $8.4,8.9,9.5,18.9$ and $28.7 \mathrm{~kW}$ ). The rotational speed of the engine crankshafts was changed during the tests. For each speed the fuel injection start angle was changed and mechanical vibrations were recorded in three engine axes (Fig. 3 ) - in the axis along the crankshafts, cylinders and in the vertical axis. 


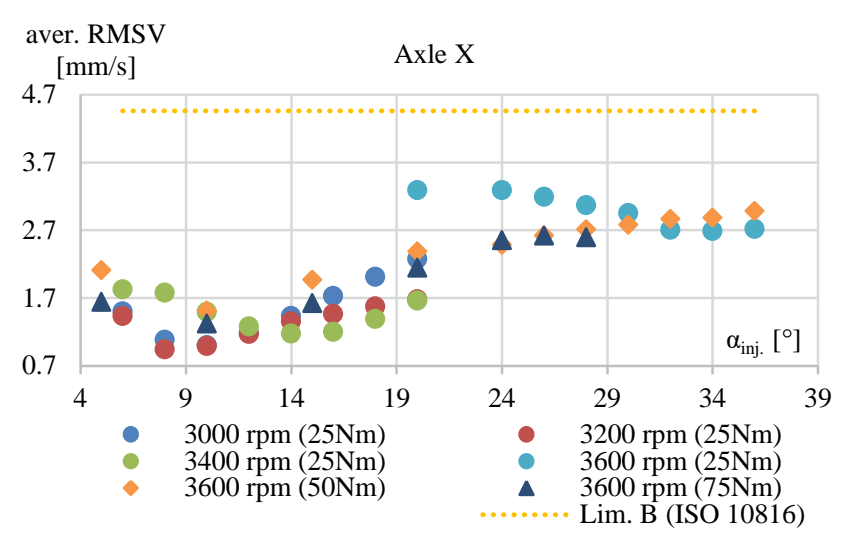

Fig. 14. Average RMS value of the vibration velocity depending on the injection angle for the $\mathrm{X}$ axis $(25,50$ and $75 \mathrm{Nm})$

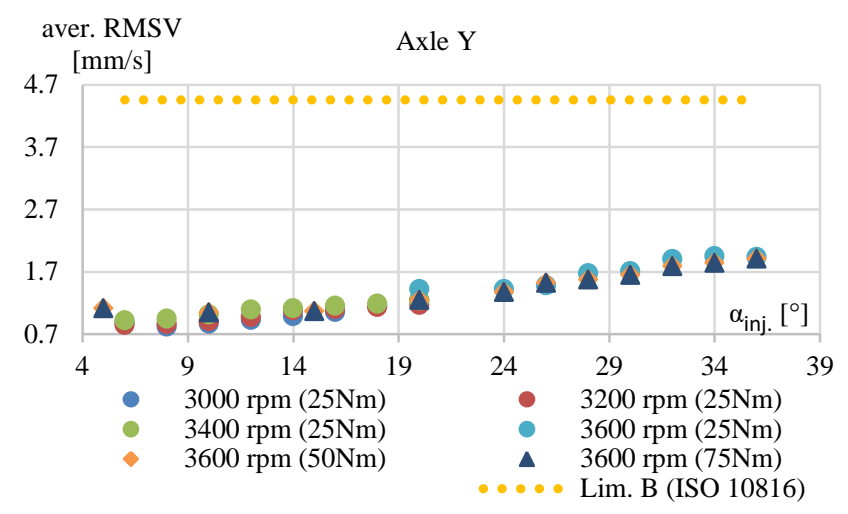

Fig. 15. Average RMS value of the vibration velocity depending on the injection angle for the $\mathrm{Y}$ axis $(25,50$ and $75 \mathrm{Nm})$

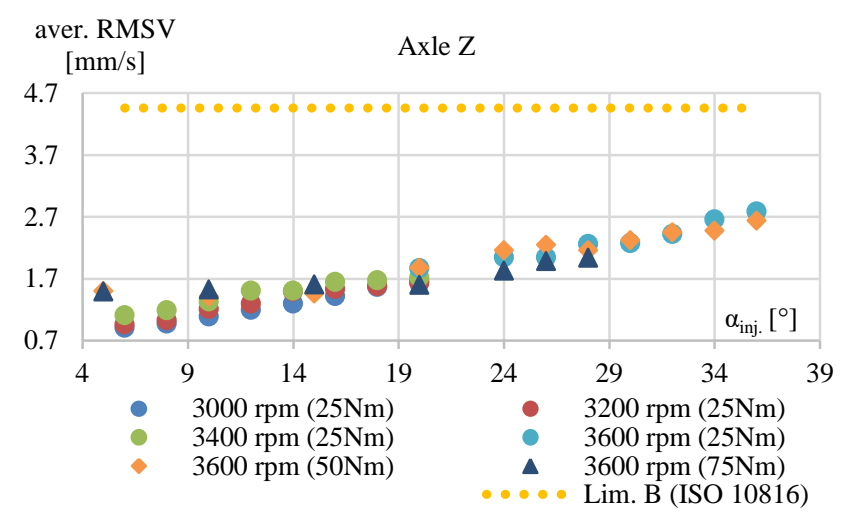

Fig. 16. Average RMS value of the vibration velocity depending on the injection angle for the $\mathrm{Z}$ axis $(25,50$ and $75 \mathrm{Nm})$

The measurement signals from the accelerometers were then processed using DIAdem software. In this software, the signals were subjected to, among others, de-noising (filtering) and integration. As a result of this analysis, the waveforms of velocity and acceleration values of mechanical vibrations and average RMS values for all measuring points of the research engine were obtained (Figs 14-16).
The results obtained in this way were compared with the legal regulations concerning the measurement of mechanical vibrations in technical machines. The representative of such legal act is the In of machine ISO 10816-6-Mechanical vibration - Evaluation vibration by measurements on non-rotating parts. The presented research engine PZL-100 falls under Part 6: Reciprocating machines with power ratings above $100 \mathrm{~kW}$. Figure 17 shows the range of acceptable values of mechanical vibrations for reciprocating engines according to ISO 10816-6. Furthermore, this standard specifies general conditions and procedures for the measurement and evaluation of vibrations, using measurements performed on non-rotating and non-reversing parts of reciprocating machines. It applies to rigidly or resiliently mounted reciprocating machinery with a rated power exceeding $100 \mathrm{~kW}$. The general assessment criteria presented apply to both in-service monitoring and acceptance testing. They are also used to ensure that the vibrations of the machine do not have a negative effect on equipment directly mounted on the machine. The standard divides reciprocating machinery into 7 classes, depending on engine power, displacement, design or crankshaft speed (Fig. 17). According to the standard, the priority for piston engines is the average RMS value for the displacement speed of the engine block, while internal combustion piston engines are placed between class 5 and 7 .

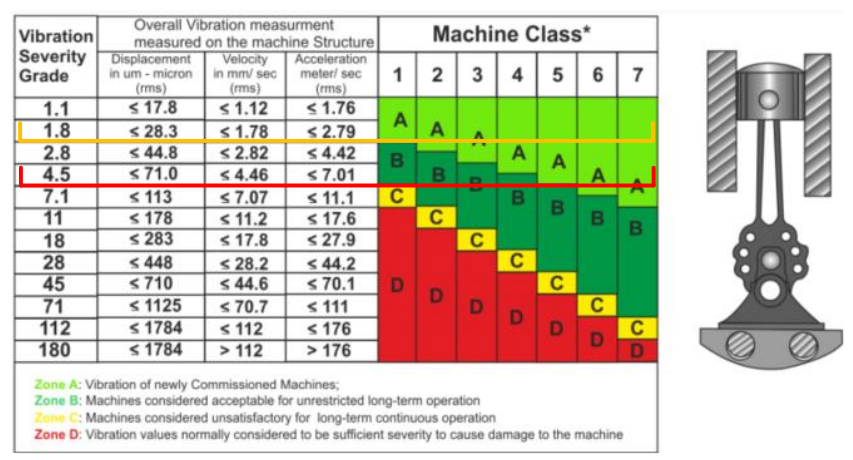

Fig. 17. Range of mechanical vibration values for internal combustion engines depending on engine class - ISO 10816-6 [12]

With reference to ISO 10816 standard, the PZL-100 engine can be qualified to A/B class (Fig. 17), that is the machine suitable for unlimited long-term exploitation - none of the measurement points of vibration velocity in different dynamic states of the engine has exceeded the value of 4.46 $\mathrm{mm} / \mathrm{s}$.

\section{Acknowledgements}

This work has been realized in cooperation with The Construction Office of WSK "PZL-KALISZ" S.A." and is part of Grant Agreement No. POIR.01.02.00-00-0002/15 financed by the Polish National Centre for Research and Development.

\section{Nomenclature}

CAD Computer Aided Design

RMS Root Mean Square
ISO International Organization for Standardization 


\section{Bibliography}

[1] BROOKE, L. Advancing the OP engine on three fronts. SAE International. 2021. Www.sae.org

[2] CHANGMING, H., SICHUAN, X. The investigation of self-balanced property and vibration on the particular crankshaft system for an opposed piston engine. SAE Technical Paper 2016-01-1768. 2016.

https://doi.org/10.4271/2016-01-1768

[3] CZARNIGOWSKI, J., WENDEKER, M., JAKLIŃSKI, P. et al. Model of injection system for SI radial aircraft engine. SAE Technical Paper 2007-01-1903. 2007. https://doi.org/10.4271/2007-01-1903

[4] CZYŻ, Z., KARPIŃSKI, P., SKIBA, K. CFD investigation of the aerodynamic characteristics of the autogyro with a double tail stabilizer. Journal of Physics: Conference Series. 2021, 1736, 1-8.

https://doi.org/10.1088/1742-6596/1736/1/012045

[5] CZYŻ, Z., WENDEKER, M., RACZYŃSKI, R. Koncepcja hybrydowego statku powietrznego z napędem wielowirnikowym. Logistyka. 2014, 6, 2936-2945.

[6] GECA, M., WENDEKER, M., LITAK, G. Combustion variability and uniqueness in cylinders of a large power radial engine. Journal of Vibroengineering. 2012, 14(2), 582590.

[7] GRABOWSKI, Ł., PIETRYKOWSKI, K., KARPIŃSKI, P. Energetic analysis of the aircraft diesel engine. MATEC Web of Conferences. 2019, 252, 1-6.

https://doi.org/10.1051/matecconf/201925205012

Michał Biały, MEng. - Faculty of Technical Sciences, Pope John Paul II State School of Higher Education in Biała Podlaska.

e-mail:m.bialy@dydaktyka.pswbp.pl

Łukasz Grabowski, DEng. - Faculty of Mechanical Engineering at the Lublin University of Technology. e-mail:.l.grabowski@pollub.pl
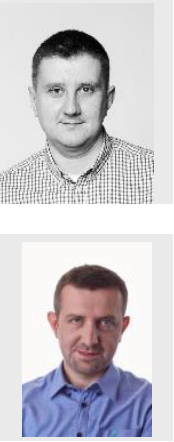

[8] GRABOWSKI, Ł., SOCHACZEWSKI, R., BARAŃSKI, G. et al. Research into a fuel supply system in the aircraft diesel opposed engine. 2020 IEEE 7th International Workshop on Metrology for AeroSpace (MetroAeroSpace). 2020, 620-624. https://doi.org/10.1109/MetroAeroSpace48742.2020.9160096

[9] HOFBAUER, P. Opposed piston opposed cylinder (OPOC) engine for military ground vehicles. SAE Technical Paper 2005-01-1548. 2005. https://doi.org/10.4271/2005-01-1548

[10] HUO, P.W., QIU, J.S. Analysis of self-balance characteristics of OPOC engine. Advanced Materials Research. 2011, 211-212, 93-96.

https://doi.org/10.4028/www.scientific.net/AMR.211-212.93

[11] MAGRYTA, P., GECA, M. FEM analysis of piston for aircraft two stroke diesel engine. MATEC Web of Conferences. 2019, 252, 1-6.

https://doi.org/10.1051/matecconf/201925207004

[12] Mechanical vibration ISO 10816. Online Browsing Platform http://www.iso.org. 2021.

[13] MIKALSEN, R., ROSKILLY, A.P. A computational study of free-piston diesel engine combustion. Applied Energy. 2009, 86(7-8), 1136-1143. https://doi.org/10.1016/j.apenergy.2008.08.004

[14] PCB, PiezoElectronics. Model 352C03 2021. http://www.pcb.com. 2021.

[15] PIRAULT, J.P., FLINT, M. Opposed piston engines evolution, use and future applications. Publisher SAE International. 2010.

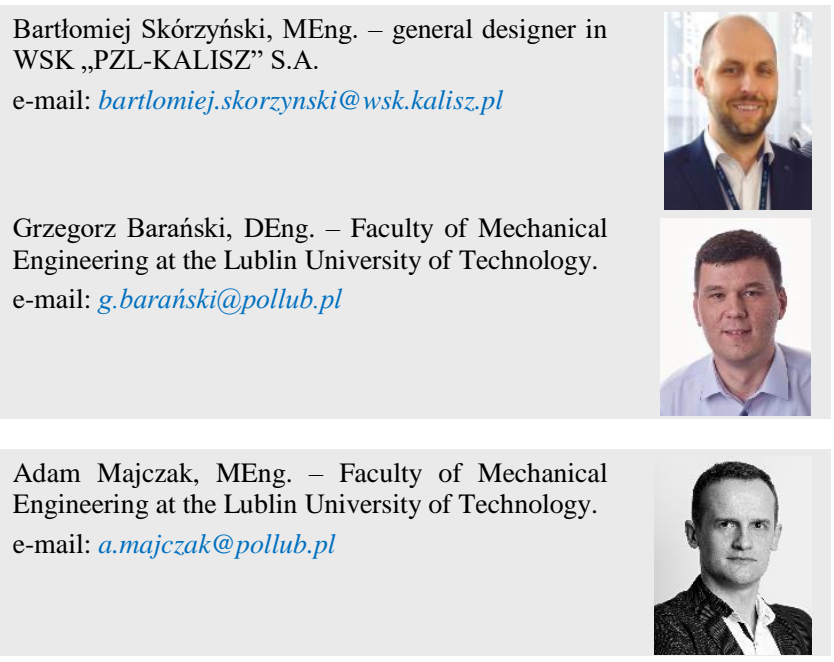
Engineering at the Lublin University of Technology. e-mail: g.barański@pollub.pl 